\title{
Sistem Ekonomi Kapitalis
}

\author{
Ainan Radiyah \\ Fakultas Ekonomi dan Bisnis Islam, Universitas UIN Alauddin Makassar
}

\section{Ainanradiyah51806@gmail.com}

Pada era Revolusi Inggris yang di perkirakan pada abad ke-17 di yakini sebagai pertumbuhan kapitalisme bersamaan dengan kebangkitan para kaum borjuis yang merupakan Pemimpin dan ahli waris utama revolusi di prancis. Menurut sejarawan Perancis, alasan utama revolusi prancis adalah superpower kaum borjuis yang bertentangan dengan bangsawan yang memaksa ingin mempertahankan hak-hak istimewa. Sedangkan kaum borjuis sendiri memandang dirinya sedang menyelamatkan masyarakat dengan cita-cita yang jelas. Namun sejauh ini, kaum borjuis telah membawa perubahan dalam dunia perekonomian yang menjadi awal mula hadirnya sistem ekonomi kapitalis. (Zainol Hasan \& Mahyudi, 2020).

Di dalam buku Mark Skousen oleh George Stiger dengan judul "Sejarah Pemikiran Ekonomi Sang Maestro” berpandangan bahwa kapitalisme sebagai model ekonomi dengan persaingan bebas (kebebasan kepememilikan individu) dari paham sang pelopornya Adam Smith yaitu "mahkota permata" dalam karyanya the wealth of nations (Sirajuddin, 2019). Kapitalisme adalah sebuah sistem perekonomian yang bercirikan kepemilikan hak privat terhadap alat-alat produksi dan distribusi yang pemanfaatannya untuk mencapai keuntungan sebanyak banyaknya dengan biaya produksi seminim mungkin. Sistem ekonomi kapitalis juga di definisikan sebagai sistem yang memberikan kebebasan yang besar bagi pelaku ekonomi dalam melaksanakan kegiatan ekonomi. Karenanya, sistem ini menganggap bahwa Labor atau tenaga kerja menerima upah berdasarkan jam kerja atau prestasinya. Dalam hal ini, peran pemerintah sangat minim, yaitu hanya sebatas pengamat dan pengatur regulasi. (Agustiati, 1929) 
Terlepas dari melihat sejarah, perkembangan kapitalisme global di era ini sudah sangat canggih, fleksibel dan kompleks. Mengapa demikian? Karena keserakahan kaum borjuis atau penganut kapitalisme ini bukan hanya pada pemerasan upah tenaga kerja atau kaum buruh dan pencaplokan pengusaha kelas teri, tetapi sudah sampai pada keserakahan yang akhirnya menjarah di sejumlah sector atau bidang yang lain. Dengan dukungan yang mereka ciptakan sendiri melalui beberapa lembaga, mereka menginginkan pertumbuhan secara cepat. Salah satu caranya yaitu menciptakan lembaga perbankan yang fungsi utamanya untuk menguras dana masyarakat secara cepat, agar secepatnya mereka dapat menambah modal perusahaannya untuk menjadi besar dengan cepat. Namun nyatanya, adanya lembaga perbankan ini belum memuaskan mereka, sehingga kaum kapitalis masih mengembangkan kreatifitasnya dengan ide untuk meraup dana yang lebih besar, salah satunya dengan menciptakan pasar unik, yang kemudian di beri nama pasar saham.(Radlyah, 2008)

Beberapa Pilar-pilar Ekonomi Kapitalis antara lain ;

1. Hak milik Swasta atau Private Property merupakan elemen paling utama dari kapitalisme, yang mana berpandangan bahwa setiap individu memiliki hak untuk mendapatkan alat-alat produksi secara legal, dengan mengadakan perjanjianperjanjian sesuai aturan Negara.

2. Dibina oleh tangan yang tak terlihat (The Invisibel Hand) prinsip ini berpandangan bahwa Setiap orang memiliki motivasi untuk menggapai kepuasan terbesar dengan cara sedemikian rupa melalui pengorbanan yang sekecil-kecilnya

3. Individualisme ekonomi atau Laissez- Faire beranggapan bahwa dengan tidak adanya intervensi pemerintah, maka dapat menimbulkan individualism ekonomi dan kebebasan ekonomi. Dalam Hal ini, intervensi pemerintah sangat terbatas.

4. Persaingan dan pasar-pasar bebas (free market competition). 
Para kapitalis berprinsip bahwa dengan bekerjanya mekanisme pasar yang bebas tanpa intervensi pemerintah, maka akan menyebabkan adanya persaingan dan menimbulkan pasar-pasar yang bebas. (Untari, 2018)

Agustiati. (1929). Sistem Ekonomi Kapitalisme. Sistem Ekonomi Kapitalisme, 152166.

Radlyah, H. jan. (2008). Eksistensi Sistem Ekonomi Kapitalis di Indonesia. Encyclopedia of Finance, 125-125. https://doi.org/10.1007/0-387-26336-5_888

Sirajuddin, T. (2019). Rekonstruksi Konseptual Kepemilikan Harta Perspektif Ekonomi Islam (Studi Kritis Kepemilikan harta sistem ekonomi Kapitalis). Laa Maysir, 6(2), 211-225.

Untari, A. (2018). Sistem Ekonomi Kapitalisme di Indonesia. Kompas.Com, 152166.

https://www.kompasiana.com/anjar06683/5b14dfe7f13344441f6655b2/sistemekonomi-kapitalisme-di-indonesia

Zainol Hasan, \& Mahyudi, M. (2020). Analisis terhadap Pemikiran Ekonomi Kapitalisme Adam Smith. Istidlal: Jurnal Ekonomi Dan Hukum Islam, 4(1), 24 34. https://doi.org/10.35316/istidlal.v4i1.206 